\section{Identification of Harvest Maturity Indicators for 'Hass' Avocado Adaptable to Field Conditions}

\author{
Pablo Rodriguez ${ }^{1,4}$, Juan Camilo Henao ${ }^{1}$, Guillermo Correa ${ }^{2}$, and \\ Ana Aristizabal ${ }^{3}$
}

ADDITIONAL INDEX WORDs. mature, index, fat content, dry matter, weather conditions

Summary. 'Hass' avocado (Persea americana) is a fruit in high demand in international markets, and Colombia is expanding its export to the United States. Avocado quality and shelf life are related to its harvest time. However, there is not enough information on harvest indicators in Colombia that allow producers to adequately harvest fruit to comply with market requirements. Therefore, the aim of this study was to estimate maturity indicators during two harvest periods. We harvested fruit between the years 2016 and 2017 in eight farms distributed in three regions of the Department of Antioquia, Colombia, and selected those in the postanthesis stages. We assessed variables such as fruit color, weight, dimensions, oil content (OC), and dry matter (DM). The results were analyzed using simple and multiple regressions as well as by principal component analysis (PCA). The results showed a high linear relation between DM and OC $\left(R^{2} \geq 78.88\right)$ and a significant relation between OC, rainfall, fruit development time, and environmental temperature. Nondestructive indicators that allow the establishment of DM in the field $\left(R^{2} \geq 73.57\right)$ varied according to the region and included fruit color $\left(L^{*}, b^{*}\right)$, volume $(P \leq 0.05)$, and fruit development time. These indicators could reduce maturity heterogeneity during the harvest period.

$\mathrm{F}$ or the past few years, the cultivation of 'Hass' avocado in Colombia has resulted in an increase in fruit production and export to the United States and European markets, primarily to the Netherlands, England, and Spain. According to the Ministerio de Agricultura y Desarrollo Rural (2016), the cultivated area in

We thank the project "Technological, productive and commercial development of avocado in the Department of Antioquia" "Desarrollo tecnológico, productivo y comercial del aguacate en el departamento de Antioquia"), under the Special Cooperation Agreement for Research No. 4600001078, subscribed by the Secretary of Agriculture (Department of Antioquia) and Universidad Nacional de Colombia at Medellín, as the framework in which we carried out this study, and Act of Accession No. 2 "Harvest and postharvest indexes for 'Hass' avocado in Antioquia: compliance with the rules and requirements of international markets" in which the Corporación Colombiana de Investigación Agropecuaria Corpoica and CORPOAGUACATE were active participants.

${ }^{1}$ Corporación Colombiana de Investigación Agropecuaria - Corpoica, Centro de Investigación La Selva, Kilómetro 7, Vía a Las Palmas, vereda Llano Grande, Rionegro Antioquia, Colombia

${ }^{2}$ Facultad de Ciencias Agrarias, Universidad Nacional de Colombia Sede Medellín, Calle 59 A No. 63-20, Medellín, Colombia

${ }^{3}$ Programa de Maestría en Innovación Alimentaria y Nutrición, Corporación Universitaria Lasallista, Carrera 51 No. 118 sur Caldas, Antioquia, Colombia

${ }^{4}$ Corresponding author. E-mail: pabloerf@gmail.com or prodriguezf@corpoica.org.co.

https://doi.org/10.21273/HORTTECH04025-18
2016 reached 16,000 ha, resulting in export amounts ranging from 18,000 to 29,000 t between 2009 and 2017 . This was equivalent to 53 million USD in 2017 , and avocados became the third most commonly exported fruit in Colombia after bananas and plantains [Musa sp. (Departamento Nacional de Estadística, 2017)]. However, despite these numbers, avocado producers in the country do not have sufficient information on harvest maturity indicators. Packaging companies have established DM values as their commercial indicators, ranging from $23 \%$ and $30 \%$ DM according to their experience. Antioquia is one of the main departments in Colombia cultivating and exporting this fruit, due to its particular soil and climatic conditions that allow fruit production all year round.

Gamble et al. (2010) have reported that harvest time can affect fruit quality, shelf life, sensory acceptability, and market opportunity. In addition, Burdon et al. (2013) found that under cold chain conditions, fruit harvested too mature are more susceptible to internal pulp disorders, in contrast to fruit with greater DM values, which have a greater sensory acceptability by consumers (Arpaia et al., 2003).

Fruit exported from Colombia to Europe are stored at least $14 \mathrm{~d}$ under cold conditions ( 5 to $7^{\circ} \mathrm{C}$ ). Therefore, due to the aforementioned reasons, the establishment of an adequate harvest maturity index has significant economic importance (Bayram et al., 2016). Hodgkin (1928) reported OC in fruit to be a maturity index. However, because OC measurement is not easily adaptable to field conditions, different studies and protocols conclude that DM can be used as a standard indicator for harvest maturity because of its close relation with OC and because it is cheaper and faster to establish (Lee et al., 1983). In addition, nondestructive techniques such as near infrared spectroscopy were reported by different authors to be indicators for harvest maturity. However, Blakey (2016) found that it is not possible to create a model that allows for the identification of the precise maturity stage of a fruit. Alternatively, Bergh and Chen (1989) and Ranney et al. (1992), described how avocado producers in Florida have used the loss of skin brightness, size, and weight in fruit as harvest indicators.

In Colombia, there is insufficient information regarding horticultural maturity indices for 'Hass' avocados. In the Department of Antioquia, Columbia, a minimum of $23.5 \% \mathrm{DM}$ has been reported as necessary to obtain an OC of $11.2 \%$ (Carvalho et al., 2014). However, this study showed that values differed according to the orchard in which they were cultivated. In addition, it is necessary to have nondestructive indicators to be

\begin{tabular}{llll}
\hline $\begin{array}{l}\text { Units } \\
\text { To convert U.S. to SI, } \\
\text { multiply by }\end{array}$ & U.S. unit & SI unit & $\begin{array}{l}\text { To convert SI to U.S., } \\
\text { multiply by }\end{array}$ \\
\hline 29.5735 & $\mathrm{fl} \mathrm{oz}$ & $\mathrm{mL}$ & 0.0338 \\
0.0929 & $\mathrm{ft}^{2}$ & $\mathrm{~m}^{2}$ & 10.7639 \\
25.4 & inch $(\mathrm{es})$ & $\mathrm{mm}$ & 0.0394 \\
0.9072 & $\mathrm{ton}(\mathrm{s})$ & $\mathrm{t}$ & 1.1023 \\
10.7639 & $\mathrm{~W} / \mathrm{ft}^{2}$ & $\mathrm{~W} \cdot \mathrm{m}^{-2}$ & 0.0929 \\
$\left({ }^{\circ} \mathrm{F}-32\right) \div 1.8$ & ${ }^{\circ} \mathrm{F}$ & ${ }^{\circ} \mathrm{C}$ & $\left({ }^{\circ} \mathrm{C} \times 1.8\right)+32$
\end{tabular}

\footnotetext{
Horthathog $\cdot$ December $201828(6)$
} 
used in different flowering periods, since in this region, the crop has several fruiting periods during the year. Therefore, the aim of this study was to assess variables associated with fruit development to verify their use as harvest indicators for different localities in Antioquia.

\section{Materials and methods}

STUdy SITE AND SAMPLING. Samples of 'Hass' avocado fruit were obtained from eight global good agricultural practices-certified orchards distributed in three growing regions in Department of Antioquia, Colombia: two in the northern region, two in the southwestern region, and four in the eastern region: La Escondida [LE (lat. $06^{\circ} 05^{\prime} 57.0^{\prime \prime} \mathrm{N}$, long. $\left.75^{\circ} 26^{\prime} 19.9^{\prime \prime} \mathrm{W}\right)$ ], Los Abuelos [LA (lat. 06 $11^{\prime} 39.8^{\prime \prime} \mathrm{N}$, long. $\left.75^{\circ} 13^{\prime} 59.2^{\prime \prime} \mathrm{W}\right)$ ], El Guarango [EG (lat. $06^{\circ} 02^{\prime} 50.1^{\prime \prime} \mathrm{N}$, long. 75 29'42.1"W)], El Banco [EB (lat. $06^{\circ} 29^{\prime} 39.6^{\prime \prime} \mathrm{N}$, long. $\left.\left.75^{\circ} 31^{\prime} 42.0^{\prime \prime} \mathrm{W}\right)\right]$, Cantabria de La Sierra [CS (lat. $06^{\circ} 29^{\prime} 23.8^{\prime \prime} \mathrm{N}$, long. 75³1'29.1" $\left.\mathrm{W}\right)$ ], Bella Vista $\left[\mathrm{BV}\right.$ (lat. $05^{\circ} 35^{\prime} 50.2^{\prime \prime} \mathrm{N}$, long. $75^{\circ} 48^{\prime} 19.8^{\prime \prime} \mathrm{W}$ )], Imperio [IM (lat. $06^{\circ} 01^{\prime} 41.2^{\prime \prime} \mathrm{N}$, long. $\left.75^{\circ} 40^{\prime} 39.3^{\prime \prime} \mathrm{W}\right)$ ], and $\mathrm{El}$ Cebadero [EC (lat. $06^{\circ} 01^{\prime} 41.9^{\prime \prime} \mathrm{N}$, long. $\left.\left.75^{\circ} 27^{\prime} 25.2^{\prime \prime} \mathrm{W}\right)\right]$. Furthermore, the soil orders for each orchard were Entisols (LE), Andisols (BV, LA, EG), Mollisols (IM), Oxisols (CS, EC), and Inceptisols (EB).

In each orchard, we randomly selected 30 trees (unknown rootstocks) between 7 and 10 years of productive age. Each time blooming occurred, a total of 800 fruit were tagged with a tape in the peduncle after fruit set (Fig. IA and B), as described by Alcaraz et al. (2013). When the fruit diameter reached 20 to $23 \mathrm{~mm}$ [fruit with atypical coloring, blotchy peduncles, peduncle banding, and black fruit coloring (Fig. 2)], among other abscission symptoms, were discarded (Delgado and Villanueva, 2014).

Tagging was carried out throughout 2016 and 2017 to identify different fruit development periods corresponding to various fruit setting cycles and to guarantee an adequate representation of the fruit population available in different periods. We inspected all trees in each locality every $15 \mathrm{~d}$ to tag fruit appropriately. Eleven harvests were carried out in each tagging period from week 20 after fruit postanthesis until the DM was greater than 29\% (week 58) as described by Rocha-Arroyo et al. (2011) and Cerdas and Montero (2014), including several modifications.

Fruit HARVEST. Four fruit were sampled in each harvest date. Fruit were harvested manually with previously disinfected pruning scissors, leaving $5 \mathrm{~mm}$ of the peduncle as described by Waissbluth and Valenzuela (2007). We harvested in the morning, verifying that the fruit was dry to avoid mechanical damage by friction. Each fruit was labeled and placed separately in a paper bag and later sent to Corpoica (Centro de Investigación La Selva, Rionegro, Colombia) for further analysis.

Agroclimatic CHARACTERISTICS IN EXPERIMENTAL SITES. Climatic conditions were monitored in weather stations (WatchDog 2900ET; Spectrum Technologies, Plainfield, IL) equipped with sensors to measure and register temperature every $15 \mathrm{~min}$ (minimum, maximum, and mean), relative humidity (percent), solar radiation (watts per square meter), photosynthetically active radiation [PAR (micromoles photons per square meter per second)], and rainfall (millimeters).

Physical analysis. We measured the physical variables as follows.

Weight: The weight (grams) of the whole fruit was measured with a precision balance (PE 360 DeltaRange; Mettler Toledo, Greinfensee, Switzerland).

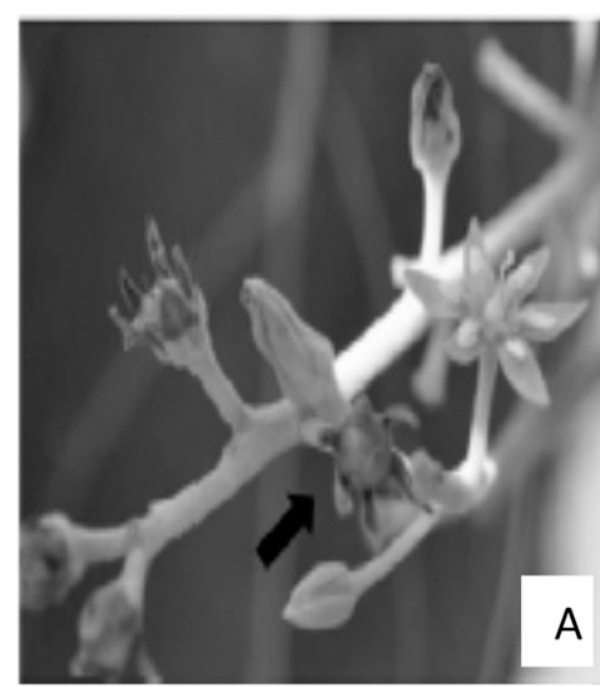

Fig. 1. (A) 'Hass' avocado at fruit setting stage according to Alcaraz et al. (2013) and (B) tagged fruit.

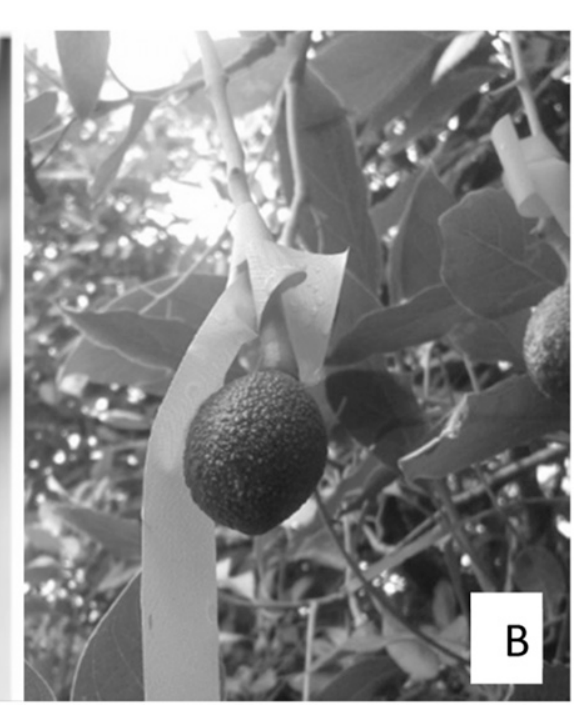

Color: The fruit epidermis color was established in the equatorial diameter using tristimulus colorimetry (HunterLab; Hunter Associates Laboratory, Reston, VA) using a portable colorimeter $\left[2^{\circ}\right.$ Standard $\mathrm{Ob}$ server and Illuminant condition $\mathrm{C}$ (CR400; Konica Minolta Sensing, Osaka, Japan)]. Data were expressed in the color space used by CIELab for $\mathrm{L}^{*}$ (lightness), $\mathrm{a}^{*}$ (redness), $\mathrm{b}$ * (yellowness), $\mathrm{C}$ (Chroma), and $\mathrm{h}^{\circ}$ (hue) coordinates.

Dimensions: We used a Vernier caliper (United Precision Machine, Shenzhen, China) to measure equatorial and longitudinal diameter per fruit, and we then calculated the estimated volume assuming the fruit had a stable ellipsoid form.

Volume: The estimated volume was calculated as described by Bayram et al. (2016) using the following equation:

$$
\begin{aligned}
& \text { estimated fruit volume (milliliters) } \\
& =\frac{1 \pi}{6} a b c 0.00093
\end{aligned}
$$

where $\mathrm{a}$ is the polar diameter of the fruit, $b$ is the transverse equatorial diameter, $\mathrm{c}$ is the longitudinal equatorial diameter, and 0.00093 is an adjustment parameter established for 'Hass'.

Chemical analysis. We measured the DM at the postharvest laboratory of Corpoica and the OC at the Basic Sciences Laboratories of Corporación Universitaria Lasallista 


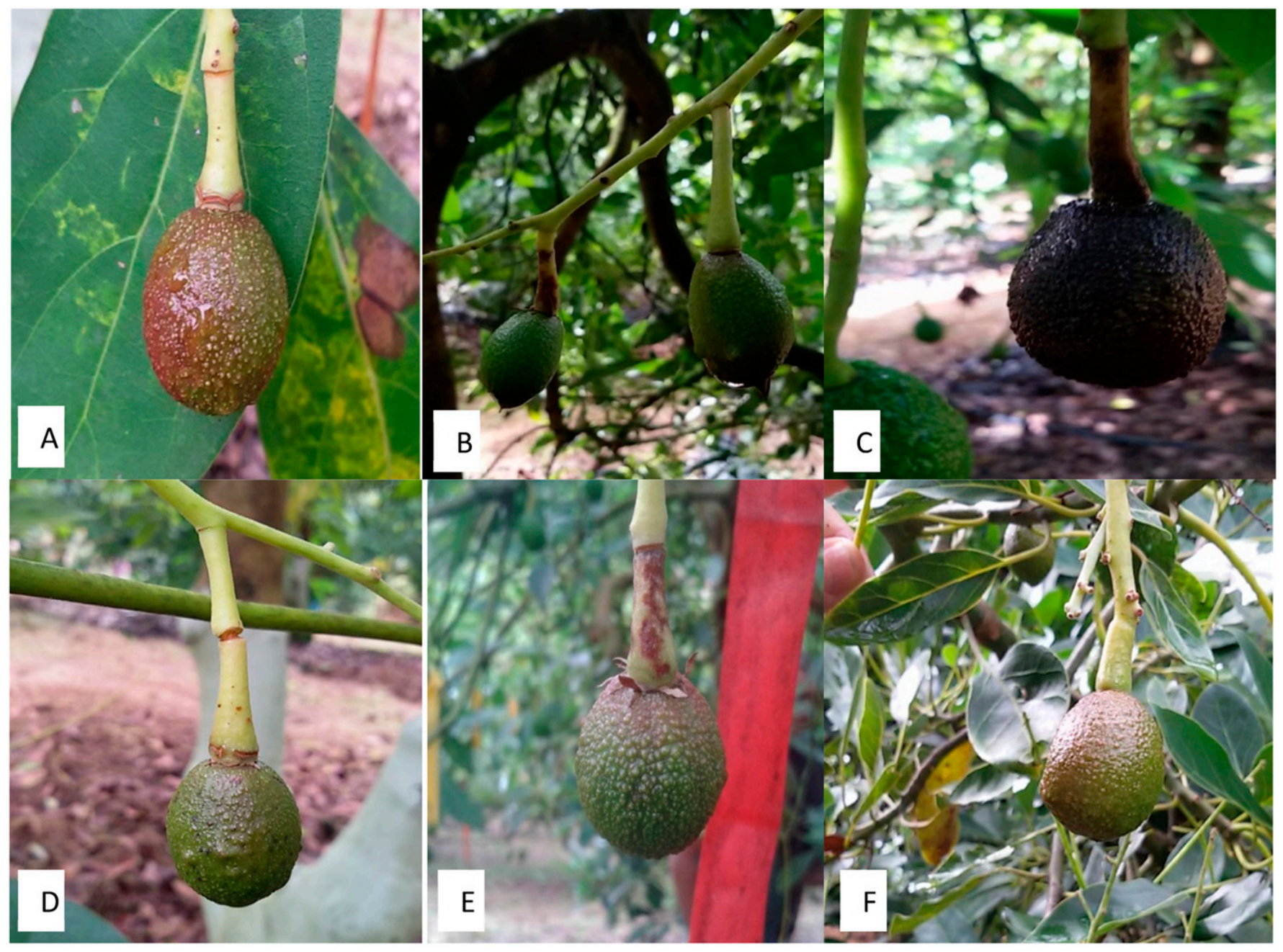

Fig. 2. 'Hass' avocado fruit abscission symptoms: (A) light purple coloring, (B) blotchy peduncle, (C) black fruit, (D) peduncle banding, (E) purple coloring in peduncles and skin, and $(\mathrm{F})$ overexposure to sun.

(Caldas, Colombia) using gravimetric methods described in American Organization of Analytical Chemists numbers 934.01 (AOAC, 1998) and 963.15 (AOAC, 2006), respectively. We used the following equations:

DM (percent by weight)

$$
\begin{aligned}
= & \frac{\text { total weight of } \mathrm{DM}-\text { weight of dish }}{\text { total weight of fresh avocado flesh }} \\
& \times 100
\end{aligned}
$$

OC (percent by weight)

$$
=\frac{\text { total weight of fat content }}{\text { weight }(\text { grams }) \text { of test sample }} \times 100
$$

Statistical analysis. Correlation models between $\mathrm{OC}$ and $\mathrm{DM}$ : We analyzed the OC and DM results using a simple linear regression analysis with a $95 \%$ confidence level. In addition, we obtained the probability value, correlation coefficient, coefficient of determination $\left(R^{2}\right)$, and an adjusted model for each farm and region and for the Department of Antioquia according to the following equation:

$$
y=a+b x
$$

where $y$ corresponds to OC, $x$ corresponds to DM, a corresponds to the intercept, and $b$ corresponds to the slope.

In addition, a regression line comparison was carried out to establish whether there were significant differences between the intercept and the slope for the harvest data (primary and secondary) with a $95 \%$ confidence level.

To evaluate the effect of climatic variables, the results also were analyzed using descriptive multivariate
(PCA) and multiple regression statistics by steps forward with a $95 \%$ confidence level.

'Hass' avocado harvest indices in Antioquia: For each of the three regions in the Department of Antioquia, we applied a multiple linear regression model by steps forward with a $95 \%$ confidence level (see Eq. [5]). The DM was used as the $\Upsilon$ variable and all nondestructive variables, i.e., the time from tagging until harvest, colorimetric variables $\left(L^{*}, a^{*}, b^{*}, C^{*}\right.$, and $\left.h^{\circ}\right)$, equatorial and polar diameter, and estimated fruit volume, as predictor variables.

$$
\begin{aligned}
\mathrm{DM}= & \beta 0+\beta 1 X 1+\beta 2 X 2 \\
& +\beta 3 X 3 \ldots \beta n X n
\end{aligned}
$$

where vector $X$ are all possible variables that represent DM variation adequately and vector $\beta$ are the parameters 
associated with them. Then, we obtained an $R^{2}$ for each region.

Finally, we analyzed the entire dataset using Statgraphics Centurion XVI software (StatPoint Technologies, Warrenton, VA).

\section{Results}

Relation of OC vs. DM. Table 1 and Fig. 3 show the results obtained using simple linear regression applied to the OC $(y)$ and the DM $(x)$. The probability values for Antioquia and the three regions were less than 0.05 , indicating a significant linear relation between the OC and the DM at a 95\% confidence level. There is a strong relationship between variables due to their correlation coefficients showing values ranging from 0.88 to 0.99 . Moreover, $R^{2}$ values ranging from $78.88 \%$ to $98.92 \%$ indicate that the models explain more than $78 \%$ of the variability in the OC.

According to Lee et al. (1983) and Arpaia et al. (2003), to obtain consumer acceptance, the fruit must have an OC greater than $11.20 \%$. Taking this value as a reference, the DM content values were based on regression equations obtaining values that ranged from $22.96 \%(\mathrm{BV})$ to $24.95 \%(\mathrm{~EB})$. These are similar to the ones reported by Carvalho et al. (2014) and close to the maturity indicator values $(24 \% \mathrm{DM})$ reported from New Zealand (Pak, 2002).

When comparing different simple regression lines obtained for farms and harvest periods (main and secondary) in the three regions of Antioquia, we found there were no significant differences $(P \leq 0.05)$ between the slopes of the regression lines.

OC vs. Climatic VARiables. To evaluate the effect of climatic variables (maximum, minimum, and mean temperature; mean relative humidity; mean PAR; mean solar radiation and rainfall) and fruit development time, we carried out a PCA (Fig. 4). The first and the second components explain $63.04 \%$ of the variability (37.46\% for the first and $25.57 \%$ for the second). Moreover, DM and OC are highly correlated as previously discussed. Tagging time, rainfall, and temperature were in the positive side of the first component and have a greater weight. In contrast, solar radiation and $P A R$ were located in the left side, showing negative values for the first component.

To assess the relation between climate values and fruit development time, we carried out a multiple regression analysis using the $\mathrm{OC}$ as the dependent variable. Three of the predictor variables included in the analysis had a significant relationship with the OC $[P \leq 0.05$ (Table 2 )]. In the northern region, the fruit development time had a proportional direct relationship compared with the OC $\left(R^{2}=78.78 \%\right)$. For example, as the fruit development time increases, the OC also increases, and this behavior was similar for the three regions studied. In the southeastern region, in addition to the fruit development time, the OC is related to the maximum environmental temperature $\left(R^{2}=74.13 \%\right)$ in a directly proportional way. For the eastern region, in addition to the fruit development time, the mean temperature and rainfall had a statistically significant relation with the OC $\left(R^{2}=77.81 \%\right)$. This behavior was similar to the consolidated value for the three regions studied.

In addition, our results are similar to the ones reported in the literature. Ozdemir and Topuz (2004) stated that the OC in the fruit mesocarp increases with age or the fruit development time. In addition, the $\mathrm{OC}$ in the fruit increases when using irrigation or according to rainfall (Kalmar and Lahav, 1977), since it is associated with an increase in the metabolic rate (Claassens and Kruger, 1997).

Similarly, the OC has shown to be affected by orchard location and by mean and minimum temperatures (Kaiser and Wolstenholme, 1994; Requejo-Tapia et al., 2000). In our study, we did not observe any significant relation with the minimum temperatures. However, the maximum temperatures showed a relation with OC, similar to the results obtained from fruit cultivated in the El Maipo, Aconcagua, La Ligua, and Petorca valleys in Chile (Ferreyra et al., 2016). In addition, the authors found that the palmitic acid content in the mesocarp increases with temperature, whereas the oleic acid content decreases. This suggests an effect of temperature on the lipid metabolism of the avocado during its development.

Maturity indices. Studies published by Lee (1981) and Olarewaju (2014) have stated the previous difficulty in determining the state of maturity of 'Hass' avocados, since the

Table 1. Correlation between the oil content [OC (\%)] and dry matter [DM (\%)] of 'Hass' avocado for three regions of the Department of Antioquia, Colombia $(n=475)$.

\begin{tabular}{|c|c|c|c|c|c|c|c|}
\hline Region & Municipality & Farm code $\cos ^{\mathrm{z}}$ & Correlation equation & Correlation coefficient & $R^{2}$ & $P$ & $\mathrm{DM}(\%)$ \\
\hline \multirow[t]{2}{*}{ North Antioquia } & San Pedro & $\mathrm{EB}$ & $\mathrm{OC}=-4.78+(0.64 \times \mathrm{DM})$ & 0.88 & 78.88 & 0.0006 & 24.95 \\
\hline & San Pedro & CS & $\mathrm{OC}=-4.90+(0.68 \times \mathrm{DM})$ & 0.89 & 80.69 & 0.0001 & 23.59 \\
\hline \multirow{3}{*}{ East Antioquia } & El Retiro & EG & $\mathrm{OC}=-6.80+(0.72 \times \mathrm{DM})$ & 0.99 & 98.92 & 0.0054 & 24.8 \\
\hline & El Peñol & LA & $\mathrm{OC}=-4.21+(0.64 \times \mathrm{DM})$ & 0.93 & 87.67 & 0 & 24.06 \\
\hline & Rionegro & LE & $\mathrm{OC}=-2.64+(0.57 \times \mathrm{DM})$ & 0.88 & 78.43 & 0.0015 & 24.19 \\
\hline \multicolumn{3}{|c|}{ Consolidated value by region } & $\mathrm{OC}=-4.28+(0.65 \times \mathrm{DM})$ & 0.93 & 87.27 & 0 & 23.63 \\
\hline \multicolumn{3}{|l|}{ Northern Antioquia } & $\mathrm{OC}=-5.70+(0.70 \times \mathrm{DM})$ & 0.92 & 84.74 & 0 & 24.05 \\
\hline \multicolumn{3}{|l|}{ Eastern Antioquia } & $\mathrm{OC}=-3.44+(0.62 \times \mathrm{DM})$ & 0.93 & 87.26 & 0 & 23.73 \\
\hline \multicolumn{3}{|c|}{ Southwestern Antioquia } & $\mathrm{OC}=-4.40+(0.66 \times \mathrm{DM})$ & 0.93 & 87.04 & 0 & 23.39 \\
\hline
\end{tabular}

${ }^{\mathrm{z}} \mathrm{BV}=$ Bella Vista (lat. $05^{\circ} 35^{\prime} 50.2^{\prime \prime} \mathrm{N}$, long. $\left.75^{\circ} 48^{\prime} 19.8^{\prime \prime} \mathrm{W}\right), \mathrm{CS}=$ Cantabria de La Sierra (lat. 06 $29^{\prime} 23.8^{\prime \prime} \mathrm{N}$, long. $\left.75^{\circ} 31^{\prime} 29.1^{\prime \prime} \mathrm{W}\right), \mathrm{EB}=\mathrm{El} \mathrm{Banco}\left(\right.$ lat. $06^{\circ} 29^{\prime} 39.6^{\prime \prime} \mathrm{N}$, long. $\left.75^{\circ} 31^{\prime} 42.0^{\prime \prime} \mathrm{W}\right), \mathrm{EC}=\mathrm{El}$ Cebadero (lat. 06 $01^{\prime} 41.9^{\prime \prime} \mathrm{N}$, long. $\left.75^{\circ} 27^{\prime} 25.2^{\prime \prime} \mathrm{W}\right), \mathrm{EG}=\mathrm{El}$ Guarango (lat. 06 $02^{\prime} 50.1^{\prime \prime} \mathrm{N}$, long. $\left.^{\circ} 5^{\circ} 29^{\prime} 42.1^{\prime \prime} \mathrm{W}\right), \mathrm{IM}=\mathrm{Imperio}($ lat. $06^{\circ} 01^{\prime} 41.2^{\prime \prime} \mathrm{N}$, long. $75^{\circ} 40^{\prime} 39.3^{\prime \prime} \mathrm{W}$ ), LA = Los Abuelos (lat. $06^{\circ} 11^{\prime} 39.8^{\prime \prime} \mathrm{N}$, long. $\left.75^{\circ} 13^{\prime} 59.2^{\prime \prime} \mathrm{W}\right), \mathrm{LE}=\mathrm{La}$ Escondida (lat. 06 05' $57.0^{\prime \prime} \mathrm{N}$, long. $\left.75^{\circ} 26^{\prime} 19.9^{\prime \prime} \mathrm{W}\right)$. 

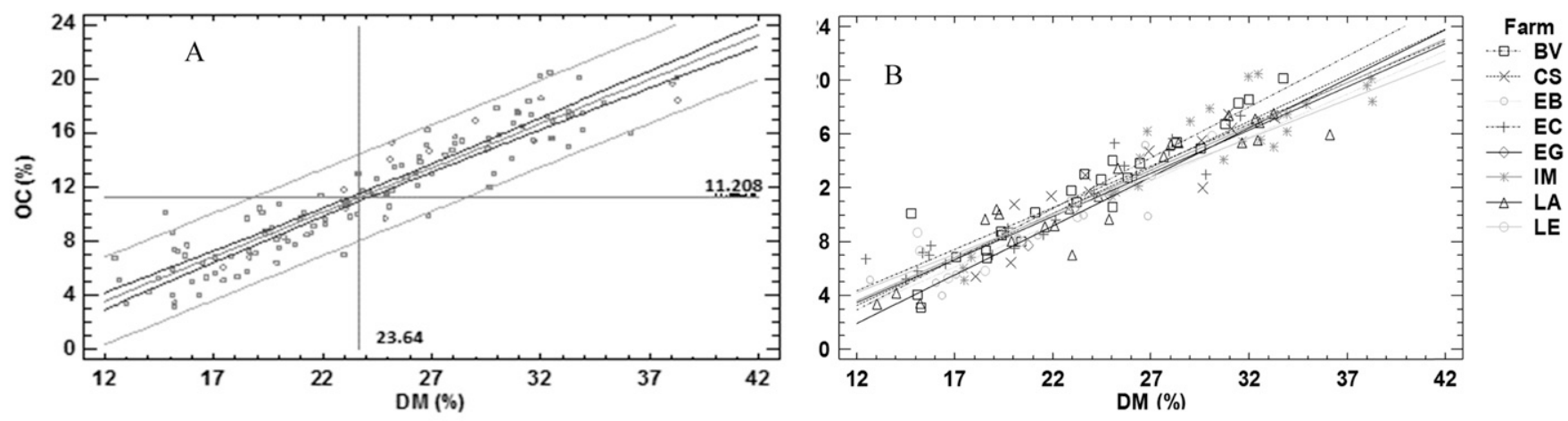

Farms codes:

$\mathrm{BV}=$ Bella Vista

$\mathrm{CS}=$ Cantabria de la Sierra

$\mathrm{EB}=\mathrm{El}$ Banco

$\mathrm{EG}=\mathrm{El}$ Guarango

$\mathrm{EL}=\mathrm{El}$ Cebadero

$\mathrm{IM}=$ Imperio

$\mathrm{LA}=$ Los Abuelos

$\mathrm{LE}=\mathrm{La}$ Escondida

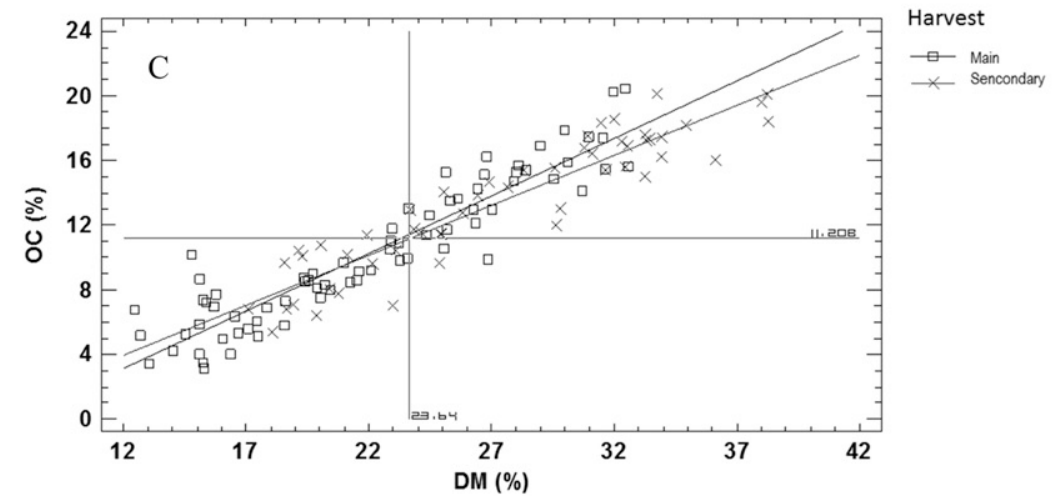

Fig. 3. (A) Linear regression between oil content (OC) and dry matter (DM) of 'Hass' avocado in eight regions of the Department of Antioquia, Colombia. (B and C) Linear regression comparison between farms and harvest periods, respectively.

fruit does not show obvious characteristics that might suggest an appropriate harvest time. This affects its quality and acceptance. Table 3 shows the results obtained in multiple regression analyses. This table shows that in the northern region of the Antioquia, the DM exhibits a direct proportional relation concerning time predictor variables and estimated fruit volume $\left(R^{2}=\right.$ $85.17 \%)$. For example, the DM increases gradually as the fruit development time also increases $(P \leq 0.05)$. Similarly, the estimated fruit volume also increases gradually, whereas the $b$ * color coordinate decreases. For the eastern region, some predictor variables had significant statistical relations over the DM (estimated fruit volume, fruit development time, and $\mathrm{L}^{*}$ color coordinate) with a multiple regression model showing $R^{2}=85.51$. In the southwest, the model also shows a directly proportional relation of time with fruit harvest. In addition, it shows an inverse proportional relation with estimated fruit value, indicating that for this region, the fruit that show greater DM values are usually of smaller size. The southeastern region showed the lowest $R^{2}$ value (79.24).

Finally, when grouping all the farms from the three regions, we established a model that can estimate
DM through the following variables: time from tagging to harvest and $\mathrm{L}^{*}$ color coordinate with $R^{2}=73.57$. Our results show that the harvest indicators used to estimate DM content vary between the regions. However, the fruit development time, color luminosity $\left(\mathrm{L}^{*}\right)$, and the fruit volume allow for the measurement of the DM in a nondestructive way.

Once we assessed the harvest variables with a significant relation to the regions assessed, we were able to establish harvest indices for each region according to commercial scenarios in Antioquia. We developed these indices considering the DM and the OC values to obtain a harvest maturity value greater than $11.20 \%$ OC. The experimental values for harvest indicators per region are as follows.

Northern region: harvest time of $217 \mathrm{~d}$, estimated fruit volume of 182.16 $\mathrm{mL}$, variation coefficient of $14.97 \%$, and $b^{*}$ color value of $24.44 \pm 1.91$; with these indicators, we obtained DM values of $23.39 \% \pm 0.67 \%$ and OC values of $12.19 \% \pm 0.33 \%$.

Eastern region: harvest time of 223 $\mathrm{d}$, estimated fruit volume of $169.23 \mathrm{~mL}$, and variation coefficient of $29.43 \%$; with these indicators, we obtained DM values of $23.63 \% \pm 0.47 \%$ and $\mathrm{OC}$ values of $11.67 \% \pm 0.74 \%$.
Southeastern region: harvest time of $199 \mathrm{~d}$, an estimated fruit volume of $181.99 \mathrm{~mL}$, variation coefficient of 20.47\%; with these indicators, we obtained DM values of $23.28 \% \pm$ $0.31 \%$ and $\mathrm{OC}$ values of $11.36 \% \pm$ $0.22 \%$.

According to Cerdas and Montero (2014), who used fruit that came from San Martín de León Cortés (Los Santos, Costa Rica), the DM content varies between $18 \%$ and $28 \%$ with fruit development setting times to harvest ranging from 31 to 44 weeks. However, our results show lower values for the northern region $(17.99 \%$ to $24.37 \% \mathrm{DM}$ ), similar to those found in the eastern region $(17.82 \%$ to $27.46 \%$ DM). However, these are lower than those found in the southwestern region (20.78\% to $29.79 \%$ DM).

\section{Conclusions}

The results showed a high correlation between the OC and DM. In addition, these values showed significant differences between regions and farms; thus, according to the OC values, it is necessary to increase harvest $\mathrm{DM}$ values to reach a commercially acceptable OC value. We found the greatest DM value in the EB farm, whereas the BV farm required lower DM values to reach an OC of $11.20 \%$. 


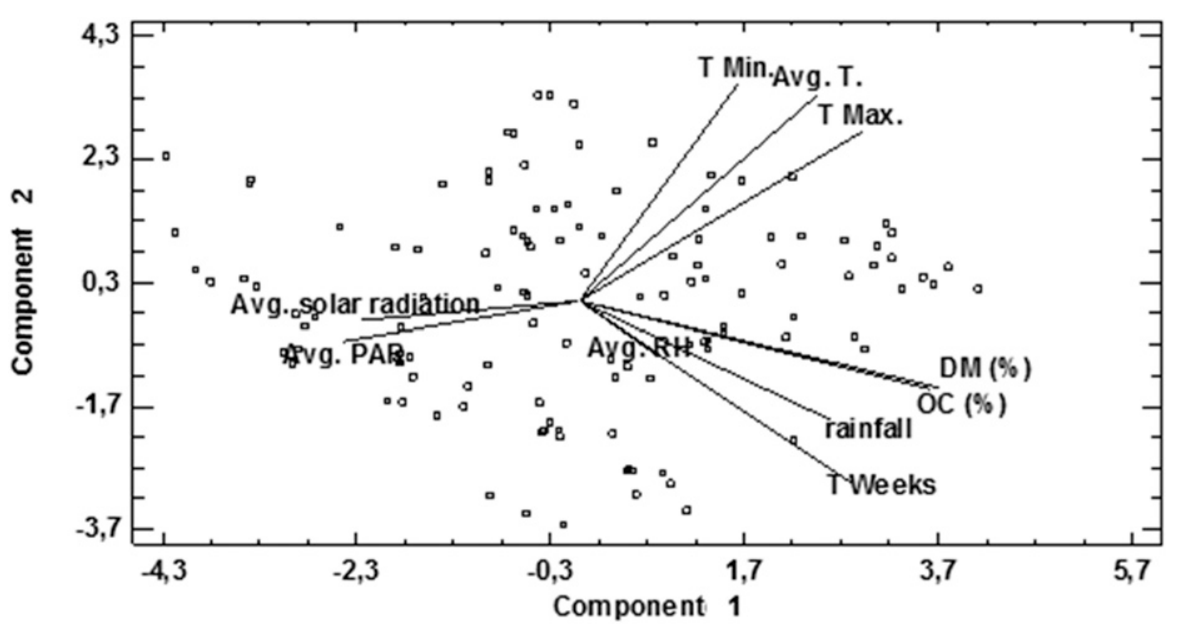

Fig. 4. Principal component analysis for the dry matter (DM), oil content (OC) of 'Hass' avocado, and climatic variables: average photosynthetic active radiation (Avg. PAR), average relative humidity (Avg. $\mathrm{RH}$ ), average (Avg.) solar radiation, average temperature (Avg. T.), fruit development time (T Weeks), maximum temperature (T Max.), minimum temperature (T Min.), and rainfall.

Table 2. Multiple regression analysis for climatic variables and the dry matter (DM) content of 'Hass' avocado in three regions of the Department of Antioquia, Colombia.

\begin{tabular}{llclc}
\hline Region & Estimated parameter $(\boldsymbol{\beta} \eta)^{\mathrm{z}}$ & Magnitude & \multicolumn{1}{c}{$\boldsymbol{P}$} & $\boldsymbol{R}^{\mathbf{2}}$ \\
\hline North Antioquia & $\beta 0$ & -3.27427 & 0.00723 & 78.78 \\
& $\beta 1$ (fruit development time) & 0.0615577 & 0 & \\
Southwest Antioquia & $\beta 0$ & -29.1658 & 0.0002 & 74.13 \\
& $\beta 1$ (fruit development time) & 0.0642495 & 0 & \\
& $\beta 2$ (maximum temperature) & 0.938323 & 0.0003 & \\
East Antioquia & $\beta 0$ & -22.2349 & 0.0008 & 77.81 \\
& $\beta 1$ (mean temperature) & 1.08529 & 0.0024 & \\
& $\beta 2$ (fruit development time) & 0.0465171 & 0 & \\
Consolidated values & $\beta 3$ (rainfall) & 0.00531163 & 0.0089 & \\
for three regions & $\beta 1$ (mean temperature) & -17.7241 & 0 & 73.46 \\
& $\beta 2$ (fruit development time) & 0.839006 & 0 & \\
& $\beta 3$ (rainfall) & 0.0574921 & 0 & \\
\hline
\end{tabular}

${ }^{2} \mathrm{DM}=\beta 0+\beta 1 X 1+\beta 2 X 2+\beta 3 X 3 \ldots \beta n X n$.

Table 3. Multiple regression analysis for harvest maturity indices of 'Hass' avocado in three regions of the Department of Antioquia, Colombia.

\begin{tabular}{llclc}
\hline Region & Estimated parameter $(\boldsymbol{\beta} \eta)^{\mathrm{z}}$ & Magnitude & $\boldsymbol{P}$ & $\boldsymbol{R}^{\mathbf{2}}$ \\
\hline North Antioquia & $\beta 0$ & 10.06 & 0.0009 & 85.16 \\
& $\beta 1$ (estimated volume) & 0.039 & 0 & \\
& $\beta 2($ time) & 0.053 & 0 & \\
East Antioquia & $\beta 3\left(\mathrm{~b}^{*}\right)$ & -0.208 & 0.02 & \\
& $\beta 0$ & 12.96 & 0.0001 & 85.51 \\
& $\beta 1$ (estimated volume) & 0.02 & 0 & \\
Southwest Antioquia & $\beta 2($ time) & 0.09 & 0 & \\
& $\beta 3$ ( $\left.\mathrm{L}^{*}\right)$ & -0.30 & 0 & \\
& $\beta 2$ (time) & 9.61 & 0 & 79.24 \\
Consolidated values & $\beta 0$ & -0.05 & 0 & \\
for three regions & $\beta 1$ (time) & 0.11 & 0 & \\
& $\beta 2$ (L*) & 20.68 & 0 & 73.58 \\
\hline
\end{tabular}

${ }^{\mathrm{z}}$ Dry matter $=\beta 0+\beta 1 X 1+\beta 2 X 2+\beta 3 X 3 \ldots \beta n X n$.
In addition, multiple relation models showed that these differences were associated with fruit development time, rainfall, and mean and maximum environmental temperatures $(P \leq 0.05)$. Furthermore, fruit development time and $\mathrm{L}^{*}$ color coordinates can be used as nondestructive harvest DM indicators for the Department of Antioquia. Therefore, time as well as estimated fruit volume should be used for the northern, near eastern and southwestern regions.

\section{Literature cited}

Alcaraz, M.L., T.G. Thorp, and J.I. Hormaza. 2013. Phenological growth stages of avocado (Persea americana) according to the $\mathrm{BBCH}$ scale. Scientia Hort. 164:434-439.

American Organization of Analytical Chemists. 1998. Official method number 934.01. Loss on drying (moisture). 17th ed. AOAC Intl., Gaithersburg, MD.

American Organization of Analytical Chemists. 2006. Official method number 963.15. Fat in cacao products Soxhlet extraction method. 18th ed. AOAC Intl., Gaithersburg, MD.

Arpaia, M.L., S.F. Donella Collin, and J. Sievert. 2003. Hass maturity project (New project: Year 1 of 1 ). Proc. California Avocado Soc. Symp. p. 120-124.

Bayram, S., S. Tepe, and R. Toker. 2016. Determination of some physical and chemical changes in fruit of Hass avocado cultivar during harvesting time. Derim 33(1):14-26.

Bergh, B. and P. Chen. 1989. Determining maturity in whole avocados. Calif. Avocado Soc. Yrbk. 73:173-176.

Blakey, R.J. 2016. Evaluation of avocado fruit maturity with a portable near-infrared spectrometer. Postharvest Biol. Technol. 121:101-105.

Burdon, J., P. Connolly, N. Silva, N. Lallu, J. Dixon, and H. Pak. 2013. A meta-analysis using a logit non-linear mixed effects model for "Hass" avocado postharvest performance data. Postharvest Biol. Technol. 86:134-140.

Carvalho, C.P., M.A. Velásquez, and Z. Van Rooyen. 2014. Determination of the minimum dry matter index for the optimum harvest of "Hass" avocado fruit in Colombia. Agron. Colomb. 32:399-406.

Cerdas, M. and C.S.O. Montero. 2014. Verificación del contenido de materia seca como indicador de cosecha para aguacate (Persea americana) cultivar Hass en zona intermedia de producción de Los Santos, 
Costa Rica. Agron. Costarric. 38:207214

Claassens, F.J. and V.E. Kruger. 1997. What went wrong with export avocado physiology during the 1996 season. South African Avocado Growers'. Assn. Annu. Res. Rpt 20:88-92.

Delgado, Y. and J. Villanueva. 2014. Identificación y evaluación de la incidencia y severidad del anillamiento del pedúnculo del aguacatero en la Sierra del Tigre, Jalisco. Thesis, Universidad Autónoma de Chapingo, Jalisco, México.

Departamento Nacional de Estadística. 2017. Comercio internacional Colombia. exportaciones. 23 Jan. 2018. <https:// www.dane.gov.co/index.php/estadisticaspor-tema/comercio-internacional/ exportaciones $>$.

Ferreyra, R., G. Sellés, J. Saavedra, J. Ortiz, C. Zúñiga, C. Troncoso, S.S. Rivera, M. González-Agüero, and B.G. Defilippi. 2016. Identification of preharvest factors that affect fatty acid profiles of avocado fruit (Persea americana Mill) cv. "Hass" at harvest. S. Afr. J. Bot. 104:15-20.

Gamble, J., F. Harker, R. Jaeger, S.R. White, A. Bava, C. Beresford, M. Stubbings, B. Wohlers, M. Hofman, P.J. Marques, and R.A. Woolf. 2010. The impact of dry matter, ripeness and internal defects on consumer perceptions of avocado quality and intentions to purchase. Postharvest Biol. Technol. 57:35-43.

Hodgkin, G.B. 1928. Oil testing of avocados and its significance. Calif. Avocado Soc. Yrbk. 13:68-72.

Kaiser, C. and B.N. Wolstenholme. 1994. Aspects of delayed harvest of 'Hass' avocado (Persea americana Mill.) fruit in a cool subtropical climate. I. Fruit lipid and fatty acid accumulation. J. Hort. Sci. 69:437-445.

Kalmar, D. and E. Lahav. 1977. Water requirements of avocado in Israel. I. Tree and soil parameters. Austral. J. Agr. Res. 28:859-868.

Lee, S.K. 1981. A review and background of the avocado maturity standard. Calif. Avocado Soc. Yrbk. 65:101-109.

Lee, S.K., R.E. Young, P.M. Schiffman, and C.W. Coggins. 1983. Maturity studies of avocado fruit based on picking dates and dry weight. J. Amer. Soc. Hort. Sci. 108:390-394.

Ministerio de Agricultura y Desarrollo Rural. 2016. Aguacate Hass colombiano entra en la recta final para exportar a Estados Unidos. 23 Jan. 2018. <https:// www.minagricultura.gov.co/Paginas/ default.aspx>.

Olarewaju, O.O. 2014. Evaluation of maturity parameters of "Fuerte" and "Hass" avocado fruit. Univ. KwaZuluNatal, KwaZulu-Natal, South Africa, MSc Thesis.
Ozdemir, F. and A. Topuz. 2004. Changes in dry matter, oil content and fatty acids composition of avocado during harvesting time and post-harvesting ripening period. Food Chem. 86:79-83.

Pak, H.A. 2002. Monitoring rates of dry matter. Avocado Growers'. Assn. Annu. Res. Rpt. 21:1-6.

Ranney, C., G. Gillette, A. Brydon, S. Mcintyre, O. Rivers, C.A. Vasquez, and E. Wilson. 1992. Physiological maturity and percent dry matter of California avocado. Proc. Second World Avocado Congr. p. 379-385.

Requejo-Tapia, L.C., R.G. Woolf, R. Schroeder, H. Young, and A. White. 2000. Avocado postharvest research: 1998/99: Seasonal changes in lipid content and fatty acid composition of "Hass" avocados. N.Z. Avocado Ind. Council, Tauranga, New Zealand.

Rocha-Arroyo, J.L., S. Salazar-Garcia, A.E. Barcenas-Ortega, I.J. GonzalezDuran, and L.E. Cossio-Vargas. 2011. Phenology of "Hass" avocado in michoacan. Rev. Mex. Cienc. Agr. 2:303-316.

Waissbluth, R. and J. Valenzuela. 2007. Determination of the minimum percentage of dry matter to authorize the harvest of Hass avocado pears for export. Proc. VI World Avocado Congr. p. 1216. 